\title{
A TUDAT FENOMENOLÓGIÁJA KÉRDŐÍV MAGYAR VÁLTOZATÁVAL SZERZETT TAPASZTALATOK
}

\author{
JÓZSA EMESE ${ }^{1}$ - KÖLTÓ ANDRÁS ${ }^{1,2}$ - BÁNYAI ÉVA ${ }^{1}$ - VARGA KATALIN ${ }^{1}$ \\ ${ }^{1}$ ELTE Eötvös Loránd Tudományegyetem Pszichológiai Intézet \\ ${ }^{2}$ National University of Ireland Galway, Health Promotion Research Centre \\ E-mail: jozsa.emese@ppk.elte.hu
}

Beérkezett: 2018. szeptember 12. - Elfogadva: 2018. december 9.

\begin{abstract}
Ebben a tanulmányban a Tudat Fenomenológiája Kérdốv (Pekala, 1982, 1991) magyar adaptációját és a kérdốv alkalmazásával kapott eredményeket foglaljuk össze. Az ötvenhárom tételból álló méröeszköz a tudat módosulásának mértékét és a szubjektív élmények mintázatát tizenkét fô- és tizennégy aldimenzió mentén méri, és a hipnózis interakciós megközelítésével összhangban nemcsak az alany, de a hipnotizốr esetében is használható. A kérdôív nem csupán hipnózisban, hanem bármilyen más helyzetben is alkalmazható, ahol a tudatállapot módosulására számítunk, így lehetốvé teszi a különféle módszerekkel létrehozott vagy spontán kialakuló módosult tudatállapotok szubjektív élményeinek összehasonlítását is. A Tudat Fenomenológiája Kérdỗiv megbizhatósága megfelelō, konstruktum-és diszkriminatív validitását számos nemzetközi és magyar vizsgálat alátámasztja. A kérdốv tehát a módosult tudatállapotok során megjelenô szubjektív élmények számszerúsitésére általánosan - és hipnózisban különösen - jól hasznositható mérōeszköz. Felhasználási lehetôségeit irodalmi összefoglalóval és kutatócsoportunk korábbi eredményeibốl származó példákkal szemléltetjük.
\end{abstract}

Kulcsszavak: módosult tudatállapotok, szubjektív élmények, fenomenológiai elemzés, hipnotikus interakció 


\section{MÓDOSULT TUDATÁLLAPOTOK}

A tudatállapot módosulását bizonyos esetekben egyedül a szubjektív élmény, a tudat átélésének változása jelzi. Emiatt sok kutató akkor is a módosult tudatállapot (MTÁ), ezen belül a hipnózis legfontosabb mutatójaként értelmezi a szubjektív élmények változását, ha azt más jellegzetességek is kísérik (Farthing, 1992/2008; Orne, 1959/2008; Rainville és Price, 2003; Sheehan és McConkey, 1982; Tart, 1972; Vaitl és mtsai, 2005).

Az MTÁ „a mentális múködés olyan általános, minôségi megváltozása, aminek alapján az élmény átélôje aktuális tudatállapotát a normális múködéstôl gyökeresen eltérônek érzékeli” (Tart, 1972, 94.). A legtöbb szerzô egyetért abban, hogy minden MTÁ esetében a minôségi változás hangsúlyos elemei a megváltozott figyelmi, képzeleti és gondolkodási folyamatok, az észlelési torzulások, a fokozott vagy csökkent szenzoros és érzelmi válaszkészség, a viselkedés tudatos kontrolljának változása, a test- és énkép és az időérzék módosulása. Jellemzô lehet még a „kimondhatatlanság”, a megfiatalodás, megújulás érzése, valamint a szuggesztiók iránti fokozott érzékenység (Farthing, 1992/2008; Ludwig, 1966; Tart, 1972).

\section{A Tudat Fenomenológiája Kérdôív szerkezete és megbizhatósága}

Pekala $(1982,1991)$ a (módosult) tudatállapotok szubjektív élményoldalának jellemzésére dolgozta ki a Phenomenology of Consciousness Inventory (a Tudat Fenomenológiája Kérdőív, PCI) elnevezésú méróeszközt, melyet Szabó (1989) fordított magyarra (1. melléklet). A papír-ceruza teszten a vizsgálati személy utólag ad önbeszámolót az átélt élményére vonatkozóan.

A kérdôív ötvenhárom ellentétes mondatpárból áll, minden mondatpár között hétfokú Likert-skálán kell megítélni, hogy az átélt állapot melyik állításhoz hasonlított, például:

A tudatom a szokásostól nagyon eltérố volt.

A tudatom nem különbözött a szokásostól.

Az egyes dimenziókhoz eltérô számú, általában két-három tétel tartozik (1. táblázat). A pontozás során a dimenziókat és aldimenziókat alkotó tételek átlagát számoljuk ki, így minden esetben 0-6 közötti értéket kapunk, a magasabb érték jelzi az adott dimenzió által mért jellegzetesség intenzívebb megjelenését az élmény során. A kérdôív alapján tehát nem egyetlen végsố pontszámot kapunk, hanem lényege éppen az a mintázat vagy profil, ami a tudatállapot módosulását az összes dimenzión mért intenzitás alapján jellemzi. A PCI bármilyen helyzetre vonatkozóan alkalmazható, így használatával összehasonlíthatóak a különféle módszerekkel létrehozott vagy spontán kialakuló MTÁ-k szubjektív élményei.

A kérdôív öt közel azonos tartalmú tételpárjából (5/35, 8/28, 12/44, 21/40, 6/45) egy belsố megbízhatósági mutató is képezhetô a pontszámkülönbségek abszolút ér- 
1. táblázat. A Tudat Fenomenológiája Kérdôív felépítése

\begin{tabular}{|c|c|}
\hline Fődimenziók & Aldimenziók \\
\hline \multirow{4}{*}{$\begin{array}{l}\text { I. Módosult élmény } \\
\text { (tizenhárom tétel, 1.+2.+3.+4. } \\
\text { aldimenzió) }\end{array}$} & $\begin{array}{l}\text { 1. Testkép: a testhatárok feloldódása } \\
\text { (három tétel: } 11,26,51 \text { ) }\end{array}$ \\
\hline & $\begin{array}{l}\text { 2. Idôérzék: az idố múlásának megváltozása } \\
\text { (három tétel: } \mathbf{1 5}, \mathbf{3 0}, 43 \text { ) }\end{array}$ \\
\hline & $\begin{array}{l}\text { 3. Percepció: a világ észlelésének változása } \\
\text { (három tétel: } \mathbf{1 7}, \mathbf{2 9}, 39 \text { ) }\end{array}$ \\
\hline & $\begin{array}{l}\text { 4. Szokatlan jelentés: transzcendens, misztikus élmények } \\
\text { megjelenése (négy tétel: } \mathbf{4}, \mathbf{2 3}, \mathbf{3 2}, 47 \text { ) }\end{array}$ \\
\hline \multirow{3}{*}{$\begin{array}{l}\text { II. Pozitív érzelmek } \\
\text { (hat tétel, } 5 .+6 .+7 \text {. aldimenzió) }\end{array}$} & 5. Élvezet: eksztázis, boldogság (két tétel: 9, 46) \\
\hline & 6. Szexuális izgalom: szexuális érzések (két tétel: $\mathbf{5}, 35$ ) \\
\hline & 7. Szeretet: szeretet érzése (két tétel: 20,49 ) \\
\hline \multirow{3}{*}{$\begin{array}{l}\text { III. Negatív érzelmek } \\
\text { (hat tétel, } 8 .+9 .+10 . \text { aldimenzió) }\end{array}$} & 8. Harag: düh, felindultság (két tétel: 14, 33) \\
\hline & $\begin{array}{l}\text { 9. Szomorúság: szomorúság, csüggedtség vagy boldogta- } \\
\text { lanság (két tétel: } 7,31 \text { ) }\end{array}$ \\
\hline & 10. Félelem: rémület vagy félelem (két tétel: $\mathbf{1 6}, 42$ ) \\
\hline \multirow[t]{2}{*}{$\begin{array}{l}\text { IV. Figyelem } \\
\text { (hat tétel, 11.+12. aldimenzió) }\end{array}$} & $\begin{array}{l}\text { 11. Figyelem iránya: a figyelem a külvilág helyett a saját } \\
\text { belsố élményekre irányul (három tétel: } \mathbf{8}, 28, \mathbf{5 2} \text { ) }\end{array}$ \\
\hline & $\begin{array}{l}\text { 12. Figyelem koncentráltsága: a figyelem összpontosítása és } \\
\text { a zavaró tényezôk figyelmen kívül hagyása } \\
\text { (két tétel: } 1, \mathbf{3 4} \text { ) }\end{array}$ \\
\hline \multirow[t]{2}{*}{$\begin{array}{l}\text { V. Vizuális képzelet } \\
\text { (négy tétel, 13.+14. aldimenzió) }\end{array}$} & $\begin{array}{l}\text { 13. Vizuális képzelet mennyisége: belsố képi élmények meg- } \\
\text { jelenése (két tétel: } 12,44)\end{array}$ \\
\hline & $\begin{array}{l}\text { 14. Vizuális képzelet élénksége: a képzeleti képek } \\
\text { valósághûnek ítélése (két tétel: } \mathbf{1 8}, 48)\end{array}$ \\
\hline
\end{tabular}

VI. Öntudat: az éber állapothoz hasonló éntudat és öntudatosság megtartottsága (három tétel: 13, 27, 50)

VII. A tudat módosultsága: a tudatállapot szokásostól eltérônek érzékelése (három tétel: 21, 40,53)

VIII. Arousal: az izmok merevnek és feszültnek érzése (két tétel: 19,37)

IX. Racionalitás: a gondolkodás tisztának és logikusnak érzékelése (három tétel: 2, 24, 36):

X. Akarati kontroll: a figyelem és gondolatok stb. akaratlagos irányítása (három tétel: $\mathbf{3 , 2 5}, 41$ )

XI. Emlékezet: az emlékek tisztasága (három tétel: 10, 22, 38)

XII. Belsố beszéd: belsố monológ megjelenése (két tétel: 6,45 )

Megjegyzés: A félkövér betûvel szedett tételek fordított pontozásúak. Bár a PCI dimenzióinál és aldimenzióinál a legtöbb esetben az intenzívebb élmény, azaz a magasabb pontszám a tudatállapot erôteljesebb változására utal, az Öntudat, a Racionalitás, az Akarati kontroll és az Emlékezet dimenziók esetében ez fordítva van (a magasabb pontszámok az éber állapothoz hasonló élményeket jeleznek).

tékét összeadva és átlagolva. A két pontnál magasabb érték esetén a személy adatait Pekala (1991) ajánlása szerint ki kell hagyni az elemzésból.

Az angol kérdôív kialakításakor Pekala (1991) három ingerhelyzetben - hipnózisban, illetve éberen csukott vagy nyitott szemmel négy percig csendben ülve - vizsgálta a PCI megbízhatóságát, és eredményei szerint az egyes dimenziók Cronbach-alfa értékei 0,52 és 0,92 között voltak, de minden dimenzió esetében legalább az egyik 
mintán elérték az általában ajánlott 0,7-es küszöbértéket. A laboratóriumunkban a PCI magyar változatával végzett addigi vizsgálatok (fóként hipnóziskísérletek) megbízhatósági adatait máshol részletesen bemutattuk (Józsa, 2012a), melyek az eredeti angol kérdôívnek megfelelôek. Ott három nagy minta (hipnóziskísérletben 1158 fö, más vizsgálati helyzetben 722 fö, az összminta 1880 fö) alapján 0,54 és 0,95 közötti Cronbach-alfa értékeket kaptunk. A magyar adatok szerint is a PCI dimenzióinak mindegyikénél a Cronbach-alfa legalább az egyik mintán elérte vagy megközelítette a 0,7-es küszöbértéket. Az esetenként alacsonyabb Cronbach-alfa értékek egyrészt tulajdoníthatók az egyes (al)dimenziókba tartozó tételek kis számának. Másrészt inkább a vizsgált mintát, illetve helyzetet jellemzik, nem önmagában a kérdôívet, hiszen az egyes aldimenziók nem ugyanannyira relevánsak minden MTÁ esetében, azonban elméletileg jól megalapozottak. A 0,7-es küszöbértéket nem ajánlott minden esetben mechanikusan alkalmazni. Exploratív vizsgálatoknál, illetve a kutatások kezdeti szakaszában alacsonyabb érték is megfelelô (pl. Cho és Kim, 2015; Schmitt, 1996; Streiner, 2003). A fentiek alapján a PCI megbízhatósági mutatóit jónak tekinthetjük.

Az elméleti faktorszerkezet alapján, 565 vizsgálati személy mintáján - akik a Harvard Hipnábilitási Csoportskálával (HCsS, Shor és Orne, 1962, magyar változat: Költő, GôsiGreguss, Varga és Bányai, 2015) végzett standard laboratóriumi csoporthipnózisban vettek részt - a huszonhat dimenziós modell megerôsítő faktorelemzése kielégítô illeszkedést mutatott (Költó, 2015).

A PCI huszonhat dimenziója igen árnyaltan jellemzi a személy tudatállapot-módosulását, azonban nem minden esetben van szükség ilyen részletes jellemzésre. Problémát jelenthet az is, hogy a kérdôív nem egyetlen végpontszámot, hanem huszonhat különbözó értékból álló profilt ad. Emiatt a PCI dimenzióinak faktoranalízisével Pekala munkacsoportja kialakított egy öt faktoralapú skálát tartalmazó értékelési rendszert is: 1. Disszociált kontroll, 2. Pozitív érzelmek, 3. Negatív érzelmek, 4. Vizuális képzelet, 5. Belsố folyamatokra irányuló figyelem (Kumar, Pekala és Cummings, 1996). Azonban a fenti faktoralapú skálákat csak standard laboratóriumi HCsS alkalmazása után felvett PCI-k alapján alakították ki, tehát más ingerhelyzetre nem alkalmazhatók automatikusan. A magyar adatokon végzett megerôsítô faktoranalízis (Varga, Józsa, Bányai, Gôsi-Greguss és Kumar, 2001) igazolta, hogy az ötfaktoros modell is jó illeszkedési mutatókkal rendelkezik.

\section{A kérdối diszkriminatív validitása: különbözố ingerhelyzetek összehasonlítása}

A PCI lehetốvé teszi a különféle indukciós módszerekkel létrehozott vagy spontán kialakuló módosult tudatállapotok szubjektív élményeinek jellemzését és összehasonlítását. A kérdőív kidolgozója, Pekala és munkatársai évtizedek óta vizsgálják a (módosult) tudatállapotok fenomenológiai jellegzetességeit különféle ingerhelyzetekben, leggyakrabban hipnózisban.

A szakirodalomban azonban számos példát találunk a PCI más területen való felhasználására is. A Pekala-munkacsoport saját eredményei szerint a PCI megbízható és érvényes mérôeszköznek bizonyult a hipnózis mellett például az éber tudatállapot (néhány percig csendben ülve nyitott vagy csukott szemmel), a relaxáció-meditáció vagy a 
monoton dobolással kísért sámánutazás-szerú transz fenomenológiai jellemzóinek vizsgálatakor, kísérleti helyzetben (Kumar és Pekala, 1988; Pekala, Kumar, Maurer et al., 2010a, 2010b; Pekala, 1991; Pekala és Kumar, 1986; Maurer et al., 1997).

Az eredeti kutatócsoporttól független adatok is születtek a PCI alkalmazásával többféle kísérleti helyzetben, ilyen például a zenehallgatás (Nagy és Szabó, 2004), vagy zenehallgatás és hipnózis kombinációja (Héjja-Nagy és Szabó, 2006); a binaurális ütemek hallgatása (Szabó, Drótos és Szabó, 2015); a sámándobolás (Kjellgren és Eriksson, 2010; Rock, Abbott és Kambouropoulos, 2008; Szabó, 2003, 2004; Szabó, Nagy és Takács, 2001; Hove és mtsai, 2016); a hipnotikus szuggesztióval indukált testenkivüliség-élmény (Facco et al., 2019); $a$ hipnózisszerú és képzeleti/disszociatív folyamatok szerepének vizsgálata a táplálkozás önszabályozásában, illetve evészavarokban (Hutchinson-Phillips, Gow és Jamieson, 2007; Vanderlinden, Spinhoven, Vandereycken és van Dyck, 1995); illetve az alkohollal kapcsolatos kulcsingerekre való érzékenység mérése során (Kambouropoulos és Rock, 2010).

Laboratóriumi körülményektôl függetlenül is sor került a PCI alkalmazására. Erre szolgáltat példát a parciális epilepsziás rohamok szubjektív élményeinek vizsgálata (Johanson, Valli, Revonsuo, Chaplin és Wedlund, 2008), ahol közvetlenül a roham után töltötték ki a betegek a kérdôívet, illetve a Kundalini meditáció gyakorlatában jártas személyek vizsgálata (Venkatesh, Raju, Shivani, Tompkins és Meti, 1997). Szintén spontán helyzetekre vonatkoznak azok a - módszertanilag külön csoportot képezó vizsgálatok, melyekben a kérdôív kitöltését nem közvetlenül az élmény átélése, hanem annak retrospektív felidézése után kérték a vizsgálati személyektôl. Ezt a módszert alkalmazták például pszichotikus állapot (Roussel és Bachelor, 2000) esetében.

Kutatócsoportunk a vizsgált jelenség természetéhez igazodva mindkét megközelítést alkalmazza. A PCI széles körú felhasználási lehetôségeire mutat példát, hogy segítségével jellemeztük már többek között a tánc (Szirmai, 2009), a légzésvisszatartás (Kuna, 2010), a szexuális együttlét (Józsa, 2012b), a szülés (Héjja-Nagy, 2013), a szinpadi elôadás (Benkô, Horpácsi és Költô, 2016), a vizsgahelyzet (Jakubovits, Kovács, NyesteJakab és Józsa, 2018), az autogén tréning és a jógázás (Józsa, Költô, Kosztolnik, Englert és Varga, 2017) szubjektív élményvilágát is.

\section{TUDATÁLLAPOT-MÓDOSULÁS HIPNÓZISBAN}

Ahogyan azt Bányai és Varga jelen tematikus számban olvasható tanulmányai is hangsúlyozzák, modern megközelítésben a hipnózis olyan rövid távú interperszonális együttmúködés, amelyet - a tudatállapot módosítása révén, adott célra irányulva hipnotizôr és alany közösen hoznak létre. A hipnóziskutatás nem hagyhatja figyelmen kívül, hogy a hipnózis nem csupán a szuggesztiókra adott viselkedéses válasz, hanem alapvetôen személyes, szubjektív élmény (Shor, 1962/2008). Ez pedig a kapcsolati elemeket (archaikus bevonódás, 1. Bányai, Józsa és Költô tanulmányát a jelen tematikus számban, pp. 45-61.) és a tudatállapot módosulását is magába foglalja.

Ezeket a jellegzetességeket hagyományosan a hipnotizált alanynak tulajdonítják. Pekala és Kumar (1987, 2000) szerint a PCI kérdôív különösen alkalmas a hipnózis alatt átélt tudatállapot szubjektív jellegzetességeinek kimutatására, azonban ôk csak 
az alanyok élményeinek leírására használják azt. A Pekala-munkacsoport több kutatása is igazolja, hogy hipnózis alatt intenzívebb szubjektív élmények mérhetôek, mint kontrollhelyzetben (pl. Kumar, Pekala és McCloskey, 1999; Pekala, 1991), illetve hogy az alanyok hipnózis alatti szubjektív élményeinek jellege összefügg hipnábilitásukkal (Pekala és Kumar, 2007). Saját vizsgálataink is megerôsítették ezeket az eredményeket (Költô és Polito, 2017; Varga, Kekecs, Myhre és Józsa, 2017).

Pekala és munkatársai a PCI-vel mért szubjektív élmények és a viselkedéses hipnábilitás kapcsolatát korrelációs és regressziós elemzések alapján sok tanulmányban dokumentálták és részletesen elemezték, ami megerôsíti a PCI megfelelố konstruktum- és prediktív validitását (Barnes, Lynn és Pekala, 2009; Kumar és Pekala, 1988; Kumar, Pekala és McCloskey, 1999; Pekala, Kumar, Maurer, Elliott-Carter, Moon és Mullen, 2010a, 2010b). A hipnábilitás és a PCI dimenziók kapcsolatát több hipnábilitásskála esetében egy összesen 829 alany adatait tartalmazó magyar mintán laboratóriumunkban is vizsgáltuk (Józsa, 2012a). A PCI tizenkét fôdimenziója közül tizenegy esetében legalább az egyik hipnózishelyzetben szignifikáns pozitív korreláció mutatkozik a hipnábilitással, kivétel a Belsô beszéd dimenzió. A legerôsebb pozitív kapcsolatot a hipnábilitás és a Módosult élmény, illetve a Módosult tudatállapot dimenzió között figyeltük meg, nemcsak egyéni, de csoportos hipnózishelyzetben is. A PCI a viselkedéses hipnábilitás hatását kontrollálva is szignifikánsan összefügg a hipnózisbeli ágenciaérzék megváltozásával, azaz az akaratlagosság hipnózisbeli csökkenése párhuzamos a tudatállapot módosulásával (Költő és Polito, 2017).

A PCI segítségével kimutatható élménymintázatok alapján Pekala és munkatársai arra is törekednek, hogy elörejelezzék a hipnábilitást (ezáltal azonosítva a hipnózis mint transzélmény szempontjából fontos jellegzetességeket), illetve elkülönítsék a különféle transztípusokat a gyenge-közepes-erôs hipnábilitású csoportok között (Pekala és Forbes, 1997; Pekala és mtsai, 2010a, 2010b). Mások felhasználják a PCI-t a hipnózis és disszociáció kapcsolatának vizsgálatában (Cleveland, Korman és Gold, 2015), vagy az erôsen hipnábilis személyek élménytípusainak elkülönítésében. Terhune és Cardeña (2010) például látens profilelemzéssel az erôsek között két csoportot különített el, a befelé forduló figyelemmel, illetve a disszociatív élményekkel jellemezhetô típust.

Saját kutatócsoportunk is sokféle módon alkalmazza a PCI-t az alanyok élményeinek jellemzésére, aminek alapján kiderült például, hogy az alanyok szubjektív élményei kapcsolatban állnak érzelemszabályozásukkal (Költő, 2015), genotípusukkal (Katonai, Szekely, Vereczkei, Sasvari-Szekely, Banyai és Varga, 2017; Katonai és Veres-Székely, 2012), a hipnózis stílusával (Varga, Bányai, Józsa és Gósi-Greguss, 2008), illetve ahogy Kasos és munkatársai tanulmánya a jelen tematikus számban (pp. 79-93.) bemutatja, az elektrodermális aktivitás révén kimutatható lateralitásváltozással, illetve az oxitocinszint változásával is.

Laboratóriumunkban 1982 óta alkalmazzuk az interakciós szemléletú szociál-pszichofiziológiai kísérleti paradigmát. Ez a gyakorlatban azt jelenti, hogy a korábban csak az alany vizsgálatára alkalmazott összes módszert - a fiziológiai reakciók regisztrálásától kezdve a szubjektív élmények kérdőíves feltárásáig - a hipnotizőrre is kiterjesztettük (1. Bányai bevezetô tanulmányát a jelen tematikus számban, pp. 7-26.). Így elôször szabad élménybeszámolók vizsgálatával (Varga, Bányai és Gôsi-Greguss, 1994) mutattuk 
ki, hogy még a standard kísérleti hipnózisok során is maguk a hipnotizôrök is mély érzelmi bevonódást és tudatmódosulást élhetnek át (Varga, Bányai és Gôsi-Greguss; 1999, 2004). Ezen eredmények alapján kezdtük meg a tudatállapot változásának kérdőíves vizsgálatát a PCI használatával hipnotizôrök esetében is.

\section{Alanyok és hipnotizôrök szubjektív élményeinek összehasonlítása}

Alanyok esetén gyakori a tudatállapot módosulásának vizsgálata, a hipnotizôrök szubjektív élményeinek vizsgálata azonban meglehetôsen elhanyagolt terület. Egy korábbi vizsgálatunkban (Varga, Józsa és Kekecs, 2014) az alanyok és hipnotizôrök szubjektív élményeit együttesen elemezve kerestük a választ arra a kérdésre, hogy vajon menynyiben hasonlítanak vagy térnek el a hipnotikus interakció résztvevôinek tudatállapot-módosulásra utaló élményei. Standard hipnábilitásmérésre szolgáló helyzetben számíthatnánk az élmények hasonlóságára, hiszen a hipnotizôrök szó szerint ugyanazt az indukciót és szuggesztiókat olvassák fel, ami az alannyal párhuzamosan akár saját magukra is hatással lehet. Ugyanakkor az alany és a hipnotizôr nagyon eltérô szerepben van az interakció során, ami eltérô élményeket is eredményezhet.

A kísérletsorozatban tizenhét hipnotizôr és 278 alany egyéni, standard kísérleti hipnózisülés - a Stanford Hipnotikus Szuszceptibilitási Skála A változatának magyar verziója (Mészáros, Bányai, Greguss, Gerber és Csókay, 1973; Weitzenhoffer és Hilgard, 1959) - után egymástól függetlenül töltötte ki a PCI-t. Az alany és a hipnotizốr PCI-pontszámai között nem volt szignifikáns korreláció. A vizsgálatban három komplex modellt alkalmaztunk, melyek a szerep (alany vagy hipnotizőr) és a hipnábilitás, illetve ezek interakciójának hatását vizsgálta a szubjektív élményekre. Eredményeink szerint a szerep alapján a huszonhat PCI dimenzió közül csak négy esetében mutatkozott szignifikáns különbség alanyok és hipnotizőrök csoportjának élményei között: a PCI Figyelem iránya, Arousal, Pozitív érzelmek és Szeretet dimenzióin.

Az alanyok és hipnotizôrök PCI-pontszámai között tehát a legtöbb esetben nincs szignifikáns különbség, ami azt jelzi, hogy hipnotikus transzélményük mintázata nagyon hasonló egymáshoz. Ugyanakkor PCI-pontszámaik szignifikáns együttjárásának hiánya arra utal, hogy az alanyok és hipnotizôrök szubjektív élményeinek intenzitása általában nem egymással párhuzamosan alakul.

\section{ÖSSZEFOGLALÁS}

A PCI a módosult tudatállapotok során megjelenô szubjektív élmények számszerúsítésére alkalmas, könnyen hasznosítható módszer, amelynek megbízhatósági mutatói megfelelóek. A mérôeszközt bármely ingerhelyzetre vonatkozóan használhatjuk, ahol a tudatállapot módosulása feltételezhetố. Diszkriminatív validitását több nemzetközi és magyar vizsgálat támasztja alá. Bár a külföldi kutatások zöme és saját kutatócsoportunk is leggyakrabban hipnózishelyzetben használja a PCI-t, a módszer kiválóan használható más MTÁ-k vizsgálatára is. 
Kutatócsoportunknak a PCI-vel hipnózishelyzetben kapott, itt csak röviden felvázolt eredményei közül az interakciós szemlélet szempontjából kiemelkedô, hogy a szubjektív élmények szintjén a hipnotizôrök ugyanolyan mértékú tudatállapot-módosulásról számolnak be, mint az alanyok (vö. Bányai, Józsa és Költố tanulmányával a jelen tematikus számban, pp. 45-61.), ugyanakkor szubjektív élményeik fenomenológiai szinten függetlenek egymástól.

Ez az eredmény több szempontból is jelentôs. Egyrészt rámutat arra, hogy a hipnózis jelenségének megértéséhez elengedhetetlen, hogy a hipnotizőrt is vizsgáljuk. Az interakciós szemléletû kutatások a hipnózissal kapcsolatban több utat is megnyitnak elôttünk: egyrészt fontosak a hipnózis hátterében meghúzódó mechanizmusok azonosításában, hiszen felvetik például egy új szinkronjelenség lehetôségét, amelynek hipnoterápiás vonatkozása is van (részletesebben l. Varga, 2017, valamint Varga tanulmánya a jelen tematikus számban, pp. 95-112.). Másrészt arra utal, hogy bár a hipnózis mindkét résztvevôje átélhet tudatmódosulást, az élményprofilok általában nem esnek egybe. Klaszteranalízissel végzett vizsgálatunkból inkább az élmények komplementer jellegére következtethetünk (Józsa, 2012a). Harmadsorban, a hipnózis fenomenológiájának és interakciós elemeinek tanulmányozása más pszichológiai jelenségek megértésében is fontos kutatási eszköz lehet (Cox és Bryant, 2008), amelyek között kiemelten fontos terület a tudat múködése (Cardeña, 2014).

\section{KÖSZÖNETNYILVÁNÍTÁS}

A PCI kérdőívet Szabó Csaba fordította magyarra. A kérdôív kutatási felhasználására laboratóriumunk a magyar fordítás megszületése óta rendelkezik engedéllyel a szerzôtôl, a magyar változat nyilvános közlésére pedig 2018-ban kaptunk engedélyt Ronald Pekalától. Kutatócsoportunk köszönetet mond a szerzőnek és a fordítónak.

\section{IRODALOM}

Bányai, É. I. (1991). Toward a social-psychobiological model of hypnosis. In S. J. Lynn, \& J. W. Rhue (Eds), Theories of Hypnosis: Current Models and Perspectives (pp. 564-598). New York, USA: Guilford Press.

Barnes, S. M., Lynn, S. J., \& Pekala, R. J. (2009). Not all group hypnotic suggestibility scales are created equal: individual differences in behavioral and subjective responses. Consciousness and Cognition, 18(1), 255-265.

Benkő C., Horpácsi D., \& Költô A. (2016). Elôadómüvészek hipnotikus fogékonysága, hipnózis és elōadás alatti módosult élményei. Poszter az Illyés Sándor Emléknapokon, 2016. március 17-18.

Cardeña, E. (2014). Hypnos and psyche: How hypnosis has contributed to the study of consciousness. Psychology of Consciousness: Theory, Research, and Practice, 1(2), 123-138.

Cho, E., \& Kim, S. (2015). Cronbach's Coefficient Alpha: Well Known but Poorly Understood. Organizational Research Methods, 18(2), 207-230.

Cleveland, J. M., Korman, B. M., \& Gold, S. N. (2015). Are hypnosis and dissociation related? New evidence for a connection. International Journal of Clinical and Experimental Hypnosis, 63(2), 198-214. 
Cox, R. E., \& Bryant, R. A. (2008). Advances in hypnosis research: Methods, designs and contributions of intrinsic and instrumental hypnosis. In M. R. Nash, \& A. J. Barnier (Eds), The Oxford Handbook of Hypnosis: Research Theory and Practice (pp. 312-336). New York, USA: Oxford University Press.

Englert V. (2016). Autogén tréning és jóga közben tapasztalt módosult tudatállapotok összehasonlítása. Pszichológia MA képzés szakdolgozata. Budapest: Eötvös Loránd Tudományegyetem Pedagógiai és Pszichológiai Kar.

Facco, E., Casiglia, E., Alkhafaji, B., Finatti, F., Marco Duma, G., Mento, G., et al. (2019). Neurophenomenology of Out-of-Body experiences induced by hypnotic suggestions. International Journal of Clinical and Experimental Hypnosis, 67(1): 39-68.

Farthing, G. W. (1992/2008). Módosult tudatállapotok. In Bányai É., \& Benczúr L. (szerk.), A hipnózis és hipnoterápia alapjai (pp. 149-166). Budapest: ELTE Eötvös Kiadó.

Héjja-Nagy, K., \& Szabó, Cs. (2006). The effect of hypnotic induction on music listening experience of high and low musical involvers. In M. Baroni, M., Adessi, A. R. Caterina, \& R. Costa (Ed.), Proceedings of the 9th International Conference on Music Perception and Cognition (pp. 893898). Bologna, Italy: Bononia University Press.

Héjja-Nagy K. (2013). A szülésélmény vizsgálata a beavatkozások összefüggésében. Perinatális szaktanácsadó szakirányú továbbképzés szakdolgozata. Budapest: ELTE Eötvös Loránd Tudományegyetem Pedagógiai és Pszichológiai Kar.

Hove, M. J., Stelzer, J., Nierhaus, T., Thiel, S. D., Gundlach, C., Margulies, D. S., et al. (2016). Brain network reconfiguration and perceptual decoupling during an absorptive state of consciousness. Cerebral Cortex, 26(7), 3116-3124.

Hutchinson-Phillips, S., Gow, K., \& Jamieson, G. A. (2007). Hypnotizability, eating behaviors, attitudes, and concerns: A literature survey. International Journal of Clinical and Experimental Hypnosis, 55(1), 84-113.

Jakubovits E., Kovács Z., Nyeste-Jakab K., \& Józsa E. (2018). Mennyire módosul a tudatállapot a vizsgák során? Elôaadás a Magyar Pszichológiai Társaság XXVII. Országos Tudományos Nagygyúlésén, Budapest, 2018. május 31. - június 2.

Johanson, M., Valli, K., Revonsuo, A., Chaplin, J. E., \& Wedlund, J.-E. (2008). Alterations in the contents of consciousness in partial epileptic seizures. Epilepsy $\mathcal{E}$ Behavior, 13(2), 366-371.

Józsa E. (2012a). Diádikus interakciós élménymintázatok. Doktori (PhD) disszertáció. Budapest: Eötvös Loránd Tudományegyetem Pszichológiai Doktori Iskola.

Józsa E. (2012b). A szeretkezés mint módosult tudatállapot fenomenológiája. In Varga K. \& Gôsiné Greguss A. (szerk.), Tudatállapotok, hipnózis, egymásra hangolódás (pp. 71-99). Budapest: L’Harmattan Kiadó.

Józsa E., Költố A., Kosztolnik L., Englert V., \& Varga K. (2017). Relaxációs hipnózis, autogén tréning és jóga során átélt szubjektív élmények összehasonlítása. Személyes tér közös világ. Kivonatkötet. A Magyar Pszichológiai Társaság XXVI. Országos Tudományos Nagygyúlése, 2017. június 1-3., Szeged, pp. 126-127.

Kambouropoulos, N., \& Rock, A. J. (2010). Quantifying Phenomenology Associated with Exposure to Alcohol-Related Cues. Imagination, Cognition and Personality, 29(3), 283-295.

Katonai, E. R., Szekely, A., Vereczkei, A., Sasvari-Szekely, M., Banyai, E. I., \& Varga, K. (2017). Dopaminergic and serotonergic genotypes and the subjective experiences of hypnosis. International Journal of Clinical and Experimental Hypnosis, 65(4), 379-397.

Katonai E. R., \& Veres-Székely A. (2012). Génváltozatok szerepe a hipnózis szubjektív megélésében In Varga K., \& Gôsiné Greguss A. (szerk.), Tudatállapotok, hipnózis, egymásra hangolódás (pp. 319-338). Budapest: L’Harmattan Kiadó.

Kjellgren, A., \& Eriksson, A. (2010). Altered states during shamanic drumming: A phenomenological study. International Journal of Transpersonal Studies, 29(2), 1-10. 
Költô, A. (2015). Hypnotic susceptibility and mentalization skills in the context of parental behavior. Doktori (PhD) disszertáció. Budapest: Eötvös Loránd Tudományegyetem Pszichológiai Doktori Iskola.

Költô, A., Gôsi-Greguss, A. C., Varga, K., \& Bányai, É. I. (2015). Hungarian norms for the Harvard Group Scale of Hypnotic Susceptibility, Form A. International Journal of Clinical and Experimental Hypnosis, 63(3), 309-334.

Költô, A., \& Polito, V. (2017). Changes in the sense of agency during hypnosis: The Hungarian version of the Sense of Agency Rating Scale (SOARS-HU) and its relationship with phenomenological aspects of consciousness. Consciousness and Cognition, 49, 245-254.

Kumar, V. K., \& Pekala, R. J. (1988). Hypnotizability, absorption, and individual differences in phenomenological experience. International Journal of Clinical and Experimental Hypnosis, 36(2), 80-88.

Kumar, V. K., Pekala, R. J., \& Cummings, J. (1996). Trait factors, state effects, and hypnotizability. International Journal of Clinical and Experimental Hypnosis, 44(3), 232-249.

Kumar, V. K., Pekala, R. J., \& McCloskey, M. M. (1999). Phenomenological state effects during hypnosis: a cross-validation of findings. Contemporary Hypnosis, 16(1), 9-21.

Kuna G. (2010). Légzés és módosult tudatállapotok. A hosszú távú légzésvisszatartás pszichés hatásai. Pszichológia MA képzés szakdolgozata. Budapest: ELTE Eötvös Loránd Tudományegyetem Pedagógiai és Pszichológiai Kar.

Ludwig, A. M. (1966). Altered states of consciousness. Archives of General Psychiatry, 15(3), 225-234.

Maurer, R. L., Kumar, V. K., Woodside, L., \& Pekala, R. J. (1997). Phenomenological experience in response to monotonous drumming and hypnotizability. American Journal of Clinical Hypnosis, 40(2), 130-145.

Mészáros I., Bányai É., Greguss A., Gerber A., \& Csókay L. (1973). Stanford Hipnotikus Szuszceptibilitási Skála A és B változata. Budapest: Eötvös Loránd Tudományegyetem Természettudományi Kar. Kézirat.

Nagy, K., \& Szabó, C. (2004). Differences in phenomenological experiences of music-listening: the influence of intensity of musical involvement and type of music on musical experiences. In S. D. Lipscomb, R. Ashley, R. O. Gjerdingen, \& P. Webster (Eds), ICMPC8. Proceedings of the 8th International conference on music perception $\mathcal{E}$ cognition. August 3-7, 2004. Evanston, IL (pp. 470-473).

Orne, M. T. (1959/2008). A hipnózis természete: mútermék és lényeg. In Bányai É., \& Benczúr L. (szerk.), A hipnózis és a hipnoterápia alapjai (pp. 167-202). Budapest: ELTE Eötvös Kiadó.

Pekala, R. J. (1982). The Phenomenology of Consciousness Inventory. Thorndale, Philadelphia, USA: Psychophenomenological Concepts.

Pekala, R. J. (1991). Quantifying Consciousness: An Empirical Approach. New York, USA: Plenum Press.

Pekala, R. J., \& Forbes, E. J. (1997). Types of hypnotically (un) susceptible individuals as a function of phenomenological experience: towards a typology of hypnotic types. American Journal of Clinical Hypnosis, 39(3), 212-224.

Pekala, R. J., \& Kumar, V. K. (1986). The differential organization of the structures of consciousness during hypnosis and a baseline condition. The Journal of Mind and Behavior, 7(4), 515-539.

Pekala, R. J., \& Kumar, V. K. (1987). Predicting hypnotic-susceptibility via a self-report instrument - a replication. American Journal of Clinical Hypnosis, 30(1), 57-65.

Pekala, R. J., \& Kumar, V. K. (2000). Operationalizing "trance”. I: Rationale and research using a psychophenomenological approach. American Journal of Clinical Hypnosis, 43(2), 107-135. 
Pekala, R. J., \& Kumar, V. K. (2007). An empirical-phenomenological approach to quantifying consciousness and states of consciousness: With particular reference to understanding the nature of hypnosis. In G. Jamieson (Ed.), Hypnosis and conscious states: The cognitive neuroscience perspective (pp. 67-194). New York, NY, US: Oxford University Press.

Pekala, R. J., Kumar, V. K., Maurer, R., Elliott-Carter, N., Moon, E., \& Mullen, K. (2010a). Suggestibility, expectancy, trance state effects, and hypnotic depth: I. Implications for understanding hypnotism. American Journal of Clinical Hypnosis, 52(4), 275-290.

Pekala, R. J., Kumar, V. K., Maurer, R., Elliott-Carter, N., Moon, E., \& Mullen, K. (2010b). Suggestibility, expectancy, trance state effects, and hypnotic depth: II. Assessment via the PCI-HAP. American Journal of Clinical Hypnosis, 52(4), 291-318.

Rainville, P., \& Price, D. D. (2003) Hypnosis phenomenology and the neurobiology of consciousness. International Journal of Clinical and Experimental Hypnosis, 51(2), 105-129.

Rock, A. J., Abbott, G. R., \& Kambouropoulos, N. (2008). Altered experience mediates the relationship between schizotypy and mood disturbance during shamanic-like journeying. Journal of Scientific Exploration, 22(3), 371-384.

Roussel, J.-R., \& Bachelor, A. (2000). Altered State and Phenomenology of Consciousness in Schizophrenia. Imagination, Cognition and Personality, 20(2), 141-159.

Schmitt, N. (1996). Uses and abuses of coefficient alpha. Psychological Assessment, 8(4), 350-353.

Sheehan, P. W., \& McConkey, K. M. (1982). Hypnosis and Experience: The Exploration of Phenomena and Process. Hillsdale, USA: Erlbaum.

Shor, R. E. (1962/2008). A hipnózis mélységének három dimenziója. In Bányai É., \& Benczúr L. (szerk.), A hipnózis és a hipnoterápia alapjai (pp. 203-216). Budapest: ELTE Eötvös Kiadó.

Shor, R. E., \& Orne, E. C. (1962) The Harvard Group Scale of Hypnotic Susceptibility. Palo Alto, CA: Consulting Psychologists Press.

Streiner, D. L. (2003) Starting at the Beginning: An Introduction to Coefficient Alpha and Internal Consistency. Journal of Personality Assessment, 80(1), 99-103.

Szabó Cs. (1989). Szubjektív élmények különbözố indukciós technikákkal létrehozott hipnózisokban. Doktori értekezés. Debrecen: Kossuth Lajos Tudományegyetem Bölcsészettudományi Kar. Kézirat.

Szabó, Cs. (2003). The effect of monotonous drumming on subjective experiences. 5th Triennial ESCOM Conference. Hannover University of Music and Drama.

Szabó, Cs. (2004). The effect of monotonous drumming on subjective experiences. Music Therapy Today, $V(1), 1-9$.

Szabó Cs. (2012). Alternatív transzállapotok, avagy hipnózis másként. In Varga K., \& Gôsiné Greguss A. (szerk.), Tudatállapotok, hipnózis, egymásra hangolódás (pp. 107-123). Budapest: L'Harmattan Kiadó.

Szabó Cs., Nagy K., \& Takács A. (2001). A folyamatos dobolás segíti a módosult tudati állapot létrejöttét. In Pléh Cs., László J., \& és Oláh A. (szerk.), Tanulás, kezdeményezés, alkotás: Barkóczi Ilona 75. születésnapjára (pp. 81-89). Budapest: ELTE Eötvös Kiadó.

Szabó G., Drótos G., \& Szabó Cs. (2015). Az elvárások és a hanginger szerepe a binaurális ütemek hallgatása során átélt szubjektív élményekre. Magyar Pszichológiai Szemle, 70(4), 769-785.

Szirmai A. (2009). Mozgás és módosult tudatállapot: A tánc transz-kivaaltó hatásának vizsgálata. Pszichológia MA képzés szakdolgozata. Budapest: Eötvös Loránd Tudományegyetem Pedagógiai és Pszichológiai Kar.

Tart, C. T. (1972). Altered states of consciousness. Oxford, England: Doubleday.

Terhune, D. B., \& Cardeña, E. (2010). Differential patterns of spontaneous experiential response to a hypnotic induction: a latent profile analysis. Consciousness and Cognition, 19(4), $1140-1150$. 
Vaitl, D., Birbaumer, N., Gruzelier, J., Jamieson, G. A., Kotchoubey, B., Kübler, A., \& Pütz, P. (2005). Psychobiology of altered states of consciousness. Psychological Bulletin, 131(1), 98-127.

Vanderlinden, J., Spinhoven, P., Vandereycken, W., \& van Dyck, R. (1995). Dissociative and hypnotic experiences in eating disorder patients: An exploratory study. American Journal of Clinical Hypnosis, 38(2), 97-108.

Varga K., Bányai É., \& Gôsiné Greguss A. (2004). A hipnotizôr a hipnotikus interakcióban: a szubjektív élmények elemzése. Pszichoterápia, 13(3), 140-147.

Varga, K., Bányai, É. I., \& Gôsi-Greguss, A. C. (1999). Hypnotists' phenomenology: Toward the understanding of hypnotic interactions. Hypnos: Swedish Journal of Hypnosis in Psychotherapy and Psychosomatic Medicine, 26(4), 181-193.

Varga K. (2017). A hipnotikus interakció fenomenológiája. Budapest: Medicina Könyvkiadó.

Varga, K., Bányai, É. I., \& Gôsi-Greguss, A. C. (1994). Parallel application of the experiential analysis technique with subject and hypnotist: A new possibility for measuring interactional synchrony. International Journal of Clinical and Experimental Hypnosis, 42(2), 130-139.

Varga, K., Bányai, É. I., Józsa, E., \& Gôsi-Greguss, A. C. (2008). Interactional phenomenology of maternal and paternal hypnosis styles. Contemporary Hypnosis, 25(1), 14-28.

Varga, K., Józsa, E., Bányai, É. I., Gôsi-Greguss, A. C., \& Kumar, V. K. (2001). Phenomenological experiences associated with hypnotic susceptibility. International Journal of Clinical and Experimental Hypnosis, 49(1), 19-29.

Varga, K., Józsa, E., \& Kekecs, Z. (2014). Comparative analysis of phenomenological patterns of hypnotists and subjects: An interactional perspective. Psychology of Consciousness: Theory, Research, and Practice, 1(3), 308-319.

Varga, K., Kekecs, Z., Myhre, P. S., \& Józsa, E. (2017). A neutral control condition for hypnosis experiments: "Wiki" text. International Journal of Clinical and Experimental Hypnosis, 65(4).

Venkatesh, S., Raju, T. R., Shivani, Y., Tompkins, G., \& Meti, B. L. (1997). A study of structure of phenomenology of consciousness in meditative and non-meditative states. Indian Journal of Physiology and Pharmacology, 41(2), 149-153.

Weitzenhoffer, A. M., \& Hilgard, E. R. (1959). Stanford Hypnotic Susceptibility Scale, Forms A and B. Palo Alto, CA: Consulting Psychologists Press. 


\section{MELLÉKLET}

\section{A PCI kérdôív}

\section{Instrukció}

Ezen a kérdôíven a belsố szubjektív élményeit, illetve a kérdéses idôszakot az alábbiakhoz hasonló állítások mentén ítélheti majd meg. A szubjektív élményeit a felsorolt állítások szerint értékelje.
1. Nagyon nyugodtnak érzem magam.
Nagyon idegesnek érzem magam.

Ezt úgy tegye majd meg, hogy az alább következô minden egyes tételnél karikázza be azt a számot, amelyik leginkább megfelel a kérdéses idôszak alatti szubjektív élményeinek. Például: ha a kérdéses idôszak alatti hangulatát „nagyon nyugodtnak” ítéli, és egyáltalán nem jellemzô, hogy „nagyon ideges” lett volna, akkor karikázza be a 0-t ennél a kérdésnél, ami a kérdôív elsô tételének felel meg.

Ezzel szemben, ha úgy érzi, hogy se az nem igaz, hogy „nagyon nyugodt” lett volna, sem pedig, hogy „nagyon ideges”, vagyis valahol a kettő között volt, akkor a válaszlapon a 3-at karikázza be. Ha a 0-t karikázza be, az azt jelenti, hogy élménye nagyon hasonló volt a bal oldali állításban megfogalmazotthoz, ha pedig a 6-ot, akkor az arra utal, hogy az élménye a jobb oldali állításban megfogalmazottnak felel meg. Ha a 0 és a 6 közötti számok valamelyikét karikázza be, az azt jelenti, hogy élménye valahol a bal és jobb oldali állítás között volt. Teljesen szabadon választhat bármelyik szám közül 0-tól 6-ig.

Tehát minden tétel esetében karikázza be azt a számot, ami leginkább megfelel a kérdéses idôszak alatti élményeinek. Kérjük, hogy ezt az elkövetkezendô oldalakon található minden egyes tételnél tegye meg, igyekezzen olyan pontosan válaszolni, amennyire csak tud.

Annak érdekében, hogy minél jobban meghatározhassa a szubjektív élményeit, leírjuk, hogy milyen értelemben használjuk a következô oldalakon az egyes kulcsfontosságú kifejezéseket:

1. ÉRZÉSEK (testi szenzációk): belsố testi érzések, amelyek tudatosulnak önben: viszketés, nyomás, fájdalom, melegség, hûvösérzés tartoznak az ilyen érzékletek körébe.

2. ÉRZÉKELÉSEK (percepciók): azok a benyomások, amelyek a külvilág felól érik. Az érzékleteket a környezetünkből képek, hangok, szagok útján vesszük fel.

3. ÉRZELMEK: belsố benyomások vagy hangulatok, pl. boldogság, öröm, harag, izgatottság stb.

4. GONDOLATOK: belsô szavak, mondatok és olyan megfogalmazások, amelyek önmagának szólnak. 
5. KÉPEK vagy KÉPZELETEK: vizuális (látvány), hallási (hangok), testérzési (bôrén vagy a testében), szaglási (szagok) vagy ízérzékelési (ízek) benyomások vagy képek, amelyek feltûnnek a képzeletében, függetlenül attól, hogy mennyire homályosak vagy tünékenyek. Ezek belülrôl erednek, és nem a külvilágból jönnek.

6. BENYOMÁSOK vagy ESEMÉNYEK: a fentiek bármelyike (pl. észlelések, érzékelések, gondolatok vagy képzeletek).

Kérjük, hogy minden megállapítást gondosan és figyelmesen olvasson el, és válaszoljon a lehetố legpontosabban: a válaszlapon jelölje meg azt a számot, amelyik a legjobban megfelel (a kérdéses idô alatt) szubjektív élményeinek.

\begin{tabular}{|c|c|c|c|}
\hline 1. & $\begin{array}{l}\text { Végig nyugtalan, zavart voltam, } \\
\text { képtelen voltam bármire is } \\
\text { koncentrálni. }\end{array}$ & $\begin{array}{lllllll}0 & 1 & 2 & 3 & 4 & 5 & 6\end{array}$ & $\begin{array}{l}\text { Jól tudtam koncentrálni, } \\
\text { egyáltalán nem voltam } \\
\text { nyugtalan (zavart). }\end{array}$ \\
\hline 2. & $\begin{array}{l}\text { A gondolkodásom tiszta és } \\
\text { világos volt. }\end{array}$ & $\begin{array}{lllllll}0 & 1 & 2 & 3 & 4 & 5 & 6\end{array}$ & $\begin{array}{l}\text { A gondolkodásom zavaros, } \\
\text { nehezen érthetố volt. }\end{array}$ \\
\hline 3. & $\begin{array}{l}\text { A felmerüló gondolatokat } \\
\text { és képeket én irányítottam, } \\
\text { magam határoztam el, hogy } \\
\text { mire fogok gondolni vagy mit } \\
\text { fogok elképzelni. }\end{array}$ & $\begin{array}{lllllll}0 & 1 & 2 & 3 & 4 & 5 & 6\end{array}$ & $\begin{array}{l}\text { A felmerüló gondolatok és } \\
\text { képek maguktól jöttek, anélkül, } \\
\text { hogy kontrolláltam volna } \\
\text { azokat. }\end{array}$ \\
\hline 4. & $\begin{array}{l}\text { Olyan élményem volt, melyet } \\
\text { nagyon vallásosnak, lelkinek } \\
\text { vagy transzcendensnek } \\
\text { nevezhetnék leginkább. }\end{array}$ & $\begin{array}{lllllll}0 & 1 & 2 & 3 & 4 & 5 & 6\end{array}$ & $\begin{array}{l}\text { Nem volt olyan élményem, } \\
\text { melyet vallásosnak, lelkinek } \\
\text { vagy transzcendensnek } \\
\text { nevezhetnék. }\end{array}$ \\
\hline 5. & $\begin{array}{l}\text { Nagyon erös szexuális érzéseim } \\
\text { voltak. }\end{array}$ & $\begin{array}{lllllll}0 & 1 & 2 & 3 & 4 & 5 & 6\end{array}$ & Nem voltak szexuális érzéseim. \\
\hline 6. & $\begin{array}{l}\text { Közben hangtalanul sokat } \\
\text { beszéltem magamban. }\end{array}$ & $\begin{array}{lllllll}0 & 1 & 2 & 3 & 4 & 5 & 6\end{array}$ & $\begin{array}{l}\text { Közben egyáltalán nem } \\
\text { beszéltem magamban, } \\
\text { hangtalanul. }\end{array}$ \\
\hline 7. & $\begin{array}{l}\text { Nagyon nagy szomorúságot } \\
\text { éreztem. }\end{array}$ & $\begin{array}{lllllll}0 & 1 & 2 & 3 & 4 & 5 & 6\end{array}$ & $\begin{array}{l}\text { Egyáltalán nem éreztem } \\
\text { szomorúságot. }\end{array}$ \\
\hline 8. & $\begin{array}{l}\text { A figyelmem teljesen saját, } \\
\text { belsô szubjektív élményeimre } \\
\text { irányult. }\end{array}$ & $\begin{array}{lllllll}0 & 1 & 2 & 3 & 4 & 5 & 6\end{array}$ & $\begin{array}{l}\text { A figyelmem teljesen a külvilág } \\
\text { felé irányult. }\end{array}$ \\
\hline 9. & Eksztázist és örömöt éreztem. & $\begin{array}{lllllll}0 & 1 & 2 & 3 & 4 & 5 & 6\end{array}$ & $\begin{array}{l}\text { Nem éreztem eksztázist vagy } \\
\text { örömöt. }\end{array}$ \\
\hline 10. & $\begin{array}{l}\text { Nem tudok visszaemlékezni } \\
\text { arra, hogy milyen élményeim } \\
\text { voltak. }\end{array}$ & $\begin{array}{lllllll}0 & 1 & 2 & 3 & 4 & 5 & 6\end{array}$ & $\begin{array}{l}\text { Pontosan emlékszem minden } \\
\text { élményemre. }\end{array}$ \\
\hline 11. & $\begin{array}{l}\text { Testem befejezôdött a bóröm } \\
\text { és a külvilág találkozásánál. }\end{array}$ & $\begin{array}{lllllll}0 & 1 & 2 & 3 & 4 & 5 & 6\end{array}$ & $\begin{array}{l}\text { Úgy éreztem, mintha a testem } \\
\text { kiterjedt volna, túl a bőröm és a } \\
\text { külvilág találkozásán. }\end{array}$ \\
\hline 12. & $\begin{array}{l}\text { Nagyon sok vizuális élményem } \\
\text { volt, sok kép jelent meg } \\
\text { elôttem. }\end{array}$ & $\begin{array}{lllllll}0 & 1 & 2 & 3 & 4 & 5 & 6\end{array}$ & $\begin{array}{l}\text { Egyáltalán nem voltak vizuális } \\
\text { élményeim, nem voltak képek }\end{array}$ \\
\hline
\end{tabular}




\begin{tabular}{|c|c|c|c|}
\hline 13. & $\begin{array}{l}\text { Egyáltalán nem voltam } \\
\text { tudatában annak, } \\
\text { hogy tudatában vagyok } \\
\text { önmagamnak (a velem } \\
\text { történteknek). Nem volt } \\
\text { éntudatom. }\end{array}$ & $\begin{array}{lllllll}0 & 1 & 2 & 3 & 4 & 5 & 6\end{array}$ & $\begin{array}{l}\text { Teljesen tudatában voltam } \\
\text { annak, hogy tudatában vagyok } \\
\text { önmagamnak. Erôs volt az } \\
\text { éntudatom. }\end{array}$ \\
\hline 14. & $\begin{array}{l}\text { Egyáltalán nem éreztem } \\
\text { magam dühösnek. }\end{array}$ & $\begin{array}{lllllll}0 & 1 & 2 & 3 & 4 & 5 & 6\end{array}$ & Dühösnek éreztem magam. \\
\hline 15. & $\begin{array}{l}\text { Teljesen megváltozott az, } \\
\text { ahogyan az idôt észleltem. }\end{array}$ & $\begin{array}{lllllll}0 & 1 & 2 & 3 & 4 & 5 & 6\end{array}$ & $\begin{array}{l}\text { Nem vettem észre, hogy } \\
\text { másképpen éreztem volna az } \\
\text { idô múlását. }\end{array}$ \\
\hline 16. & $\begin{array}{l}\text { Nagyon rémültnek éreztem } \\
\text { magam. }\end{array}$ & $\begin{array}{lllllll}0 & 1 & 2 & 3 & 4 & 5 & 6\end{array}$ & $\begin{array}{l}\text { Nem éreztem magam } \\
\text { rémültnek. }\end{array}$ \\
\hline 17. & $\begin{array}{l}\text { Egészen megváltozott az, } \\
\text { ahogyan a világot észleltem. }\end{array}$ & $\begin{array}{lllllll}0 & 1 & 2 & 3 & 4 & 5 & 6\end{array}$ & $\begin{array}{l}\text { Nem vettem észre, hogy } \\
\text { másként észleltem volna a } \\
\text { világot. }\end{array}$ \\
\hline 18. & $\begin{array}{l}\text { A vizuális képzeletem egészen } \\
\text { élénk és háromdimenziós volt, } \\
\text { valósnak tûnt. }\end{array}$ & $\begin{array}{lllllll}0 & 1 & 2 & 3 & 4 & 5 & 6\end{array}$ & $\begin{array}{l}\text { A vizuális képzeletem igen } \\
\text { halvány és diffúz volt. Nehéz } \\
\text { volt bármit is elképzelni. }\end{array}$ \\
\hline 19. & $\begin{array}{l}\text { Az izmaimat nagyon feszesnek, } \\
\text { feszültnek éreztem. }\end{array}$ & $\begin{array}{lllllll}0 & 1 & 2 & 3 & 4 & 5 & 6\end{array}$ & $\begin{array}{l}\text { Az izmaimat nagyon lazának, } \\
\text { ellazultnak éreztem. }\end{array}$ \\
\hline 20. & $\begin{array}{l}\text { Egyáltalán nem éreztem a } \\
\text { szeretet érzését. }\end{array}$ & $\begin{array}{lllllll}0 & 1 & 2 & 3 & 4 & 5 & 6\end{array}$ & $\begin{array}{l}\text { Nagyon erósen éreztem a } \\
\text { szeretet érzését. }\end{array}$ \\
\hline 21. & $\begin{array}{l}\text { A tudatom nem tért el a } \\
\text { szokásostól, nem volt semmi } \\
\text { szokatlan. }\end{array}$ & $\begin{array}{lllllll}0 & 1 & 2 & 3 & 4 & 5 & 6\end{array}$ & $\begin{array}{l}\text { A szokásostól igen eltérô, } \\
\text { szokatlan tudatállapotot } \\
\text { éreztem. }\end{array}$ \\
\hline 22. & $\begin{array}{l}\text { Semmit sem tudok felidézni } \\
\text { abból, ami történt velem. }\end{array}$ & $\begin{array}{lllllll}0 & 1 & 2 & 3 & 4 & 5 & 6\end{array}$ & $\begin{array}{l}\text { Mindent fel tudok idézni abból, } \\
\text { ami történt velem. }\end{array}$ \\
\hline 23. & $\begin{array}{l}\text { Tiszteletet és megbecsülést } \\
\text { éreztem a világ iránt. }\end{array}$ & $\begin{array}{lllllll}0 & 1 & 2 & 3 & 4 & 5 & 6\end{array}$ & $\begin{array}{l}\text { Nem éreztem tiszteletet és } \\
\text { megbecsülést a világ iránt. }\end{array}$ \\
\hline 24. & $\begin{array}{l}\text { A gondolkodásom tiszta és } \\
\text { világos volt. }\end{array}$ & $\begin{array}{lllllll}0 & 1 & 2 & 3 & 4 & 5 & 6\end{array}$ & $\begin{array}{l}\text { A gondolkodásom zavaros, } \\
\text { kusza volt. }\end{array}$ \\
\hline 25. & $\begin{array}{l}\text { Teljesen kontrolláltam azt, } \\
\text { hogy mire figyelek. }\end{array}$ & $\begin{array}{lllllll}0 & 1 & 2 & 3 & 4 & 5 & 6\end{array}$ & $\begin{array}{l}\text { Egyáltalán nem kontrolláltam } \\
\text { azt, hogy mire figyelek. }\end{array}$ \\
\hline 26. & $\begin{array}{l}\text { Testi érzéseim mintha } \\
\text { kiterjedtek volna a külvilágba. }\end{array}$ & $\begin{array}{lllllll}0 & 1 & 2 & 3 & 4 & 5 & 6\end{array}$ & $\begin{array}{l}\text { A testi érzéseim a bórömön } \\
\text { belülre korlátozódtak. }\end{array}$ \\
\hline 27. & $\begin{array}{l}\text { Végig teljesen tudatában } \\
\text { voltam önmagamnak. }\end{array}$ & $\begin{array}{lllllll}0 & 1 & 2 & 3 & 4 & 5 & 6\end{array}$ & Elvesztettem az éntudatomat. \\
\hline 28. & $\begin{array}{l}\text { A figyelmem teljesen a } \\
\text { körülöttem levố világra } \\
\text { irányult. }\end{array}$ & $\begin{array}{lllllll}0 & 1 & 2 & 3 & 4 & 5 & 6\end{array}$ & $\begin{array}{l}\text { A figyelmem teljesen befelé, } \\
\text { saját belsố, szubjektív } \\
\text { élményeim felé irányult. }\end{array}$ \\
\hline 29. & $\begin{array}{l}\text { A körülöttem levó világ színe } \\
\text { és alakja egészen megváltozott. }\end{array}$ & $\begin{array}{lllllll}0 & 1 & 2 & 3 & 4 & 5 & 6\end{array}$ & $\begin{array}{l}\text { Nem éreztem másnak a } \\
\text { körülöttem levô világ színét } \\
\text { vagy formáját. }\end{array}$ \\
\hline 30. & $\begin{array}{l}\text { Úgy túnt, hogy az idô nagyon } \\
\text { gyorsan vagy lassan telt. }\end{array}$ & $\begin{array}{lllllll}0 & 1 & 2 & 3 & 4 & 5 & 6\end{array}$ & $\begin{array}{l}\text { Nem éreztem másnak az idô } \\
\text { múlását. }\end{array}$ \\
\hline 31. & $\begin{array}{l}\text { Nem éreztem csüggedtnek } \\
\text { vagy boldogtalannak magam. }\end{array}$ & $\begin{array}{lllllll}0 & 1 & 2 & 3 & 4 & 5 & 6\end{array}$ & $\begin{array}{l}\text { Boldogtalannak, csüggedtnek } \\
\text { éreztem magam }\end{array}$ \\
\hline
\end{tabular}




\begin{tabular}{|c|c|c|c|}
\hline 32. & $\begin{array}{l}\text { Nem éreztem, hogy hirtelen } \\
\text { a szokásosnál jobban } \\
\text { megérteném a dolgok } \\
\text { lényegét. }\end{array}$ & $\begin{array}{lllllll}0 & 1 & 2 & 3 & 4 & 5 & 6\end{array}$ & $\begin{array}{l}\text { Nagyon határozottan éreztem, } \\
\text { hogy bizonyos dolgokat } \\
\text { hirtelen világosan értek. }\end{array}$ \\
\hline 33. & $\begin{array}{l}\text { Nagyon mérgesnek, } \\
\text { felindultnak éreztem magam. }\end{array}$ & $\begin{array}{lllllll}0 & 1 & 2 & 3 & 4 & 5 & 6\end{array}$ & $\begin{array}{l}\text { Nem éreztem mérgesnek, } \\
\text { felindultnak magam. }\end{array}$ \\
\hline 34. & $\begin{array}{l}\text { Nem zavart semmi, képes } \\
\text { voltam teljesen elmerülni az } \\
\text { élményeimben. }\end{array}$ & $\begin{array}{lllllll}0 & 1 & 2 & 3 & 4 & 5 & 6\end{array}$ & $\begin{array}{l}\text { A külsô hatások, események } \\
\text { végig zavartak. }\end{array}$ \\
\hline 35. & $\begin{array}{l}\text { Egyáltalán nem éreztem } \\
\text { szexuális érzéseket. }\end{array}$ & $\begin{array}{lllllll}0 & 1 & 2 & 3 & 4 & 5 & 6\end{array}$ & $\begin{array}{l}\text { Nagyon erôs szexuális érzéseket } \\
\text { éreztem. }\end{array}$ \\
\hline 36. & $\begin{array}{l}\text { A gondolkodásom irracionális } \\
\text { volt, nagyon nehéz volt } \\
\text { megérteni. }\end{array}$ & $\begin{array}{lllllll}0 & 1 & 2 & 3 & 4 & 5 & 6\end{array}$ & $\begin{array}{l}\text { A gondolkodásom logikus volt, } \\
\text { könnyú volt megérteni. }\end{array}$ \\
\hline 37. & $\begin{array}{l}\text { Nem éreztem merevnek, } \\
\text { feszültnek magam. }\end{array}$ & $\begin{array}{lllllll}0 & 1 & 2 & 3 & 4 & 5 & 6\end{array}$ & $\begin{array}{l}\text { Merevnek, feszültnek éreztem } \\
\text { magam. }\end{array}$ \\
\hline 38. & $\begin{array}{l}\text { Emlékeim, melyeket átéltem, } \\
\text { nagyon tiszták és élénkek } \\
\text { voltak. }\end{array}$ & $\begin{array}{lllllll}0 & 1 & 2 & 3 & 4 & 5 & 6\end{array}$ & $\begin{array}{l}\text { Az átélt emlékeim nagyon } \\
\text { homályosak, ködösek voltak. }\end{array}$ \\
\hline 39. & $\begin{array}{l}\text { Nem éreztem, hogy a } \\
\text { körülöttem levô világ } \\
\text { mérete, alakja vagy látványa } \\
\text { megváltozott volna. }\end{array}$ & $\begin{array}{lllllll}0 & 1 & 2 & 3 & 4 & 5 & 6\end{array}$ & $\begin{array}{l}\text { A körülöttem levó világ } \\
\text { mérete, alakja vagy látványa } \\
\text { megváltozott. }\end{array}$ \\
\hline 40. & $\begin{array}{l}\text { A tudatom a szokásostól } \\
\text { nagyon eltéró volt. }\end{array}$ & $\begin{array}{lllllll}0 & 1 & 2 & 3 & 4 & 5 & 6\end{array}$ & $\begin{array}{l}\text { A tudatom nem különbözött a } \\
\text { szokásostól. }\end{array}$ \\
\hline 41. & $\begin{array}{l}\text { Feladtam a kontrollt, passzívan } \\
\text { befogadtam az élményeimet. }\end{array}$ & $\begin{array}{lllllll}0 & 1 & 2 & 3 & 4 & 5 & 6\end{array}$ & $\begin{array}{l}\text { Akarattal kontrolláltam az } \\
\text { élményeimet. }\end{array}$ \\
\hline 42. & $\begin{array}{l}\text { Nem éreztem rémületet vagy } \\
\text { félelmet. }\end{array}$ & $\begin{array}{lllllll}0 & 1 & 2 & 3 & 4 & 5 & 6\end{array}$ & $\begin{array}{l}\text { Félelmet és nagy rémületet } \\
\text { éreztem. }\end{array}$ \\
\hline 43. & $\begin{array}{l}\text { Nem éreztem az idôtlenség } \\
\text { érzését, az idô úgy ment, ahogy } \\
\text { szokott. }\end{array}$ & $\begin{array}{lllllll}0 & 1 & 2 & 3 & 4 & 5 & 6\end{array}$ & $\begin{array}{l}\text { Az idô megállt, egyáltalán nem } \\
\text { ment. }\end{array}$ \\
\hline 44. & $\begin{array}{l}\text { Egyáltalán nem voltak képi } \\
\text { élményeim vagy csak nagyon } \\
\text { kevés. }\end{array}$ & $\begin{array}{lllllll}0 & 1 & 2 & 3 & 4 & 5 & 6\end{array}$ & $\begin{array}{l}\text { Az élményeim majdnem } \\
\text { teljesen képekből álltak. }\end{array}$ \\
\hline 45. & $\begin{array}{l}\text { Közben egyáltalán nem } \\
\text { beszéltem magamban, } \\
\text { csendben. }\end{array}$ & $\begin{array}{lllllll}0 & 1 & 2 & 3 & 4 & 5 & 6\end{array}$ & $\begin{array}{l}\text { Közben sokat beszéltem } \\
\text { magamban, csendben. }\end{array}$ \\
\hline 46. & $\begin{array}{l}\text { Nem éreztem a szokásos } \\
\text { érzéseimen túl eksztázist vagy } \\
\text { boldogságot. }\end{array}$ & $\begin{array}{lllllll}0 & 1 & 2 & 3 & 4 & 5 & 6\end{array}$ & $\begin{array}{l}\text { Eksztázist vagy nagy } \\
\text { boldogságot éreztem. }\end{array}$ \\
\hline 47. & $\begin{array}{l}\text { Nem éreztem a szokásostól } \\
\text { eltérố vallásos (misztikus) } \\
\text { érzéseket, vagy a lét mély } \\
\text { értelmét. }\end{array}$ & $\begin{array}{lllllll}0 & 1 & 2 & 3 & 4 & 5 & 6\end{array}$ & $\begin{array}{l}\text { A lét mélyen misztikussá, } \\
\text { jelentéstelivé vált. }\end{array}$ \\
\hline 48. & $\begin{array}{l}\text { Az elképzelt dolgok nagyon } \\
\text { halványak, homályosak voltak. }\end{array}$ & $\begin{array}{lllllll}0 & 1 & 2 & 3 & 4 & 5 & 6\end{array}$ & $\begin{array}{l}\text { Az elképzelt dolgok olyan } \\
\text { tiszták és élesek voltak, mintha } \\
\text { valóban láttam volna azokat. }\end{array}$ \\
\hline 49. & $\begin{array}{l}\text { Erósen éreztem a szeretet } \\
\text { érzését. }\end{array}$ & $\begin{array}{lllllll}0 & 1 & 2 & 3 & 4 & 5 & 6\end{array}$ & Nem éreztem a szeretet érzését. \\
\hline
\end{tabular}




\begin{tabular}{|c|c|c|c|}
\hline 50. & $\begin{array}{l}\text { Egész idő alatt erösen } \\
\text { tartottam az öntudatom. }\end{array}$ & $\begin{array}{lllllll}0 & 1 & 2 & 3 & 4 & 5 & 6\end{array}$ & $\begin{array}{l}\text { Nem tartottam meg az } \\
\text { öntudatom egyáltalán. }\end{array}$ \\
\hline 51. & $\begin{array}{l}\text { Végig nagyon erósen } \\
\text { fenntartottam azt az érzést, } \\
\text { hogy a környezet és én } \\
\text { különállóak vagyunk. }\end{array}$ & $\begin{array}{lllllll}0 & 1 & 2 & 3 & 4 & 5 & 6\end{array}$ & $\begin{array}{l}\text { Erôs egységet éreztem a } \\
\text { világgal, köztem és a környezet } \\
\text { között eltúntek a határok. }\end{array}$ \\
\hline 52. & $\begin{array}{l}\text { A figyelmem teljesen befelé } \\
\text { irányult. }\end{array}$ & $\begin{array}{lllllll}0 & 1 & 2 & 3 & 4 & 5 & 6\end{array}$ & $\begin{array}{l}\text { A figyelmem teljesen kifelé } \\
\text { irányult. }\end{array}$ \\
\hline 53. & $\begin{array}{l}\text { A tudatállapotom nem volt } \\
\text { szokatlan, nem tért el attól, } \\
\text { amilyen lenni szokott. }\end{array}$ & $\begin{array}{lllllll}0 & 1 & 2 & 3 & 4 & 5 & 6\end{array}$ & $\begin{array}{l}\text { Különlegesen szokatlan } \\
\text { tudatállapotban éreztem } \\
\text { magam, eltért attól, amilyen } \\
\text { lenni szokott. }\end{array}$ \\
\hline
\end{tabular}

Fordított pontozású tételek: 2-9, 12, 15-19, 23-27, 29, 30, 33-34, 38, 40, 49, 50, 52.

\title{
RESULTS WITH THE APPLICATION OF THE HUNGARIAN ADAPTATION OF THE PHENOMENOLOGY OF CONSCIOUSNESS INVENTORY
}

\author{
JÓZSA, EMESE - KÖLTŐ, ANDRÁS - BÁNYAI, ÉVA- VARGA, KATALIN
}

This study summarizes the Hungarian adaptation of the Phenomenology of Consciousness Inventory (PCI, Pekala, 1982, 1991) and the results with its application. The 53-item self-report questionnaire measures the intensity and pattern of alterations of consciousness with fourteen main and twelve subdimensions. In line with the interactional approach to hypnosis the PCI can be used not just with subjects but with hypnotists as well. The PCI can be applied not just in hypnosis but in any other situation where alterations in consciousness can be expected. Thus the PCI makes it possible to compare the subjective experiences of altered states of consciousness, either occuring spontaneously or induced by different methods. The reliability of the PCI is adequate, and it's construct and discriminative validity is supported by numerous international and Hungarian studies. The PCI is therefore a good method for the quantification of subjective experiences occuring during various types of altered states of consciousness in general, and it is an especially useful tool in hypnosis research. Various possible applications of the PCI are illustrated by a literature review and examples from previous studies of our research team.

Keywords: altered states of consciousness, subjective experiences, phenomenological analysis, hypnotic interaction

A cikk a Creative Commons Attribution 4.0 International License (https:// creativecommons.org/licenses/by/4.0) feltételei szerint publikált Open Access közlemény, melynek szellemében a cikk bármilyen médiumban szabadon felhasználható, megosztható és újraközölhetô, feltéve, hogy az eredeti szerzó és a közlés helye, illetve a CC License linkje és az esetlegesen végrehajtott módosítások feltüntetésre kerülnek. (SID_1) 